\title{
In Vitro Fertilization and the Development of Eggs Following Transfer in Genetically Diabetic Obese (db/db) Mouse
}

\author{
Hiroshi Suzuki, Saburo Shingai, Mamoru Togashi, \\ Tatsuya Mryai and Michio Oкамото \\ Drug Development Laboratories, Chugai Pharmaceutical Co., Ltd. \\ Toshimaku Tokyo 171
}

(Accepted for publication May 8, 1987)

\begin{abstract}
Summary. In vitro fertilization was performed by using gametes of diabetic obese mouse, C57BL/KsJ-dbm that is incapable of reproducing due to homozygous autosomal recessive diabetis(db). Newly ovulated eggs from $\mathrm{db} / \mathrm{db}$ mice treated with 5 i.u. PMSG and 5 i.u. hCG were inseminated in vitro with spermatozoa recovered from the cauda epididymidis. At $6 \mathrm{hr}$ after insemination, the oocytes were examined for the extrusion of 2nd polar body and the male and female pronucleus. The percentages of fertilized oocytes were $24 \%, 41 \%, 24 \%$ and $99 \%$ when oocytes were inseminated with $\mathrm{db} / \mathrm{db}$, adrenalectomized $\mathrm{db} / \mathrm{db}$ (Adrex), $\mathrm{db} /+$ and $(\mathrm{C} 57 \mathrm{BL} / 6 \mathrm{~J} \times \mathrm{C} 3 \mathrm{H} / \mathrm{HeN}) \mathrm{F} 1$ spermatozoa, respectively. The adrenalectomy could not make $\mathrm{db} / \mathrm{db}$ males regain fertility but significantly increase in vitro fertilization rate. Number of abnormal spermatozoa in Adrex was significantly fewer than that of intact $\mathrm{db} / \mathrm{db}$. Only $28 \%$ of intact $\mathrm{db} / \mathrm{db}$ and $39 \%$ of Adrex db/db cultured in the Whitten's medium containing $100 \mu \mathrm{M}$ EDTA developed into the blastocyst stage $120 \mathrm{hr}$ after insemination. As a result of the transfer of 2-cell embryos which were fertilized with Adrex spermatozoa, eleven newborn ( $\mathrm{M}: \mathrm{M}=3: 8$ ) were obtained. These results indicated that in vitro fertilization technique can be applied for amelioration of defected reproductive ability in diabetic obese $(\mathrm{db} / \mathrm{db})$ mouse. KEY WORDS; IN VITRO FERTILIZATION, C57BL/KSJ-DBM, CULTURE, ADRENALEGTOMY, TRANSFER.
\end{abstract}

Jpn J Anim Reprod 33, 96-100, 1987

\section{肥満性糖尿病（db/db）マウスの体外受精と産仔への発生能}

\author{
鈴木 宏志・新谷 参郎・富樫守・宮井 達也・岡本 道生 \\ 中外製薬株式会社開発研究所, 171 東京都豊島区高田 3 丁目
}

マウスの体外受精に関しては，Whittingham（1968） の報告以来多くの研究が積み上げられ, 現在では高い受 精率（豊田ら，1971a，1971b）と正常な産仔への発生 (Mukherjee and Cohen., 1970; Mukherjee, 1972; Hoppe and Pitts., 1973; Kasai et al., 1979; Massip et al. 1984; Suzuki and Toyoda, 1986) が報告され ている。その結果, 受精から肧盤胞までの着床前の発生 過程すべてを体外で進行させる技術が確立されている
(Mukherjee and Cohen, 1970; Mukherjee, 1972; Hoppe and Pitts, 1973; Kasai et al., 1978; Kasai et al., 1979; Massip et al., 1984; 星と豊田, 1985; Suzuki and Toyoda, 1986)。しかしながら研究材料として汎用 されている卵子および精子は, 特定の近交系およびそれ らの雑種第 1 代 (F1) 由来の配偶子で, 各種病態モデル マウスを材料とした研究はまだ少ない（横山と小島, 1985）。今回, 著者らは体外受精技術の 実験動物学分野 
への応用として，ホモ個体 $(\mathrm{db} / \mathrm{db})$ は肥満性の糖尿病を 発症し, 雌雄ともに妊朶能を持なないため, へテロ $(\mathrm{db} /$ ））同士の交配によって繁殖・維持されている $\mathrm{C} 57 \mathrm{BL} /$ $\mathrm{KsJ}-\mathrm{dbm}$ マウスに対し, 雌雄ともにホモ個体を用いて, 体外受精・胚の培養拉よび産仔への発生能について検討 した。

\section{材料と方法}

動物 実験には当研究所自家繁殖のC $57 \mathrm{BL} / \mathrm{KsJ}-\mathrm{dbm}$, $\mathrm{MRL} / \mathrm{MpJ}$ および $(\mathrm{C} 57 \mathrm{BL} / 6 \mathrm{~J} \times \mathrm{C} 3 \mathrm{H} / \mathrm{HeN}) \mathrm{F} 1$ マウ スを用いた。卵子提供動物には, 肥満性の糖尿病を呈す るホモ個体（db/db；5１3 週秢，体重 17〜 47 g）を用 い，精子提供動物には，無処置木乇個体（ $\mathrm{db} / \mathrm{db} ; 10$ 14 週齢, 体重 $42 \sim 53 \mathrm{~g}$ ), 生後 4 週齢で副腎摘出を施し たホモ個体（db/db；10１7週齢，体重31４7g，以下 Adrex と記す)，へテロ個体 (db/+; 10 21週齢, 体重 26〜31 g）拈よび F1（19 20週齢，体重34〜38g）を用 いた。なお，副腎摘出は，エーテル麻酔下で腰背部を切 開して行った。動物の飼育条件は $14 \mathrm{~L}: 10 \mathrm{D}$ (5:00点 灯, $19: 00$ 消灯）温度 $24 \pm 2^{\circ} \mathrm{C}$, 湿度 $50 \sim 60 \%$ に設定 した。飼料（CA-1；日本クレア）および 水は不断給与. とし、ポリカーボネイト製平底ケージにカンナクズを入 れて飼育した。なお，Adrex 雄については術後より給水 飞生理食塩水を与えて飼育した。

性周期の観察および排卵誘起の検討 (実験 I) 性周期 の観察は, $\mathrm{db} / \mathrm{db}$ 打よび $\mathrm{db} /+$ 雌マウスについて 9 週 齢より12日間, 15 : 00に胵スメア法により行った。 た, PMSG (PMS ゼンヤク；日本全薬工業） 2.5, 5.0 および、100 i.u.を $18 ： 00 〜 19: 00$ に皮下投与し，48時間 後に hCG(プベローゲン; 三共ゾーキ) 5 i.u. を皮下投与 して過排卵誘起処置の有効性を検討した。 hCG 投与後 15 16時間に，摘出した卵管を 2 枚のスライドグラスで はさみ，顕微鏡下で卵管膨大部内の排卵卵子数を観察し た。なお,一部については, 体外受精後に観察を行った。

体外受精および培養（実験 II） 体外受精は豊田ら （1971a）の方法に準じて行った。db/db 雌マウスに PMSG おょび hCG 各 5 i.u. の投与後, 卵管膨大部よ り採取した卵子を，流動パラフィンに覆われたプラスチ ックシャーレ (35×10 mm; Falcon) 内の $0.2 \mathrm{ml} の$ TYH（豊田ら，1971a）に導入した。精子については， 雄マウスの精巣上体尾部より採取し, $0.1 \mathrm{ml}$ の $\mathrm{TYH}$ 内で 2 時間のプレインキュベートを行った。次いで， 10 $\mu \mathrm{l}$ の精子懸濁液を, 卵子を含む培地に添加することに より体外受精を行った。体外受精時の最終精子濃度は， $500 \sim 1500$ 精子/ $\mu \mathrm{l}$ であった。授精後 6 時間に第 2 極体 の放出㧍よび雌雄両前核の認められた卵子を受精卵と判 定し, $100 \mu \mathrm{M}$ EDTA 添加 Whitten's (Whitten, 1971) 培地に移しかえ， $37^{\circ} \mathrm{C}, 5 \% \mathrm{CO}_{2}, 95 \%$ 空気の気相下で 授精後 120 時間まで培養した。泼の発生段階の観察は, 倒立顕微鏡下で24時間間隔で行った。また，少量の精子 暞濁液をスライドグラスに叙沫・風乾し，ローズベンガ ル液で染色後, 鏡検して奇形精子数を算出した。

移植（実験 III） 授精後約30時間に発生した Adrex 区の 2 細胞期胚を胵栓確認日の $\mathrm{MRL} / \mathrm{MpJ}$ 偽妊娠 雌 マウスの卵管に，以下の方法で移植した。ペントバルビ タールナトリウム（ネンブタール；アボットラボラトリ 一ズ）の腹腔内注射により麻醉を施した受容雌の左右の 腰背部を切開し，卵巣・卵管㧍よび子宮を引き出した。 次いで，卵巣のうを電気メス（サンテック，SLS-40w； サンスター技研）を用いて切開し，マウスピースに接続 したガラス毛細管ピペットを用い，少量の培地とともに 卵管一側あたり $3 \sim 4$ 個の胚を注入した。術後は, 受容 雌を個別飼育して分婏について観察した。なお一部につ いては帝王切開を施し産仔を得た。

統計処理 体外受精率および培養成績については, $\chi^{2}$ 検定を, 精子の奇形率については, 単一要因分散分析を 行った。

\section{結果}

実験 I db/+ は不規則な性周期を呈してはいたが， 全例 $(n=5)$ 飞発情期の出現が認められ，2 例は規則的な 性周期を 2 回繰り返した。一方, $\mathrm{db} / \mathrm{db}$ では全例 $(n=5)$ 観察期間中発情休止像のみが観察され, 自然排卵が起こ っていないことが示唆された。PMSG および hCG に 上る過排卵誘起 処置の 結果 (Table 1)，PMSG 2.5

Table 1. Number of ovulated oocytes after injection of PMSG and hCG

\begin{tabular}{|c|c|c|c|}
\hline \multicolumn{2}{|c|}{ Dose (i.u.) } & \multicolumn{2}{|c|}{ Numbers of ova (mean \pm S.D.) } \\
\hline PMSG ${ }^{1)}$ & hCG1) & $\mathrm{db} / \mathrm{db}$ & $\mathrm{db} /+$ \\
\hline 2.5 & 5.0 & $9.0 \pm 5.7(8)^{2)}$ & $8.2 \pm 7.6(10)$ \\
\hline 5. 0 & 5.0 & $14.2 \pm 7.5(62)$ & $14.3 \pm 7.6(26)$ \\
\hline 10.0 & 5.0 & $16.3 \pm 7.6(20)$ & $22.6 \pm 6.4(10)$ \\
\hline $\begin{array}{l}\text { 1) The } \\
\text { was } \\
\text { 2) Num }\end{array}$ & r. & en PMSG and hC & CG injections \\
\hline
\end{tabular}


Table 2. In vitro fertilization of $\mathrm{C} 57 \mathrm{BL} / \mathrm{KsJ}-$ dbm mouse eggs by epididymal sperm

\begin{tabular}{clc}
\hline Female & Male & $\begin{array}{c}\text { No. of fertilized } \\
\text { eggs/no. of eggs } \\
\text { examined } \\
(\%)\end{array}$ \\
\hline & $\mathrm{db} / \mathrm{db}$ & $115 / 482(24)^{\mathrm{a}}$ \\
$\mathrm{db} / \mathrm{db}$ & Adrex ${ }^{1)}$ & $423 / 999(41)^{\mathrm{b}}$ \\
& $\mathrm{db}^{2}+$ & $93 / 392(24)^{\mathrm{a}}$ \\
& $\mathrm{F} 1^{2)}$ & $124 / 125(99)^{\mathrm{c}}$ \\
\hline
\end{tabular}

1) Adrenalectomized $\mathrm{db} / \mathrm{db}$.

2) $\mathrm{C} 57 \mathrm{BL} / 6 \mathrm{~J} \times \mathrm{C} 3 \mathrm{H} / \mathrm{HeN}$.

Values with different superscripts are significantly different at $\mathrm{P}<0.05$.

Table 3. Abnormality of spermatozoa

\begin{tabular}{|c|c|c|c|}
\hline Strain & Genotype & $\begin{array}{c}\text { No. of } \\
\text { animals }\end{array}$ & $\begin{array}{c}\% \text { of } \\
\text { abnormal } \\
\text { spermatozoa }\end{array}$ \\
\hline \multirow{3}{*}{$\begin{array}{l}\text { C57BL/ } \\
\text { KsJ-dbm }\end{array}$} & $\mathrm{db} / \mathrm{db}$ & 12 & $54.2^{\mathrm{a}}$ \\
\hline & $\begin{array}{l}\mathrm{db} / \mathrm{db} \\
\left(^{\text {Adrex })^{1)}}\right.\end{array}$ & 11 & 42. $4^{\mathrm{b}}$ \\
\hline & $\mathrm{db} /+$ & 12 & $44.3^{\mathrm{b}}$ \\
\hline $\begin{array}{c}(\mathrm{C} 57 \mathrm{BL} / 6 \mathrm{~J} X \\
\mathrm{C} 3 \mathrm{H} / \mathrm{HeN}) \mathrm{F} 1\end{array}$ & $\ldots$ & 8 & $8.3^{\mathrm{c}}$ \\
\hline
\end{tabular}

1) Adrenalectomized $\mathrm{db} / \mathrm{db}$.

Values with different superscripts are significantly different at $\mathrm{P}<0.05$. 10.0i.u. 投与区すべてにおいて， db/db および $\mathrm{db} /+$ 全例に排卵が観察され，db/db においても PMSG-hCG 法による排卵誘起が可能であった。特に PMSG 5.0 i.u. 区では $\mathrm{db} /+$ の $14.3 \pm 7.6$ 個に対し, $\mathrm{db} / \mathrm{db}$ でも 14.2 士7.5 個で, ほぼ同数の排卵が観察された。

実験 II 授精後 6 時間における体外受精成績は, Table 2 に示す通りであった。 db/db 区および $\mathrm{db} /+$ 区 の受精率は，それぞれ $24 \%$ と低率であった。一方， Adrex 区では，41\% の卵子が受精し， db/db 区および $\mathrm{db} /+$ 区に比べ有意に高い值であった $(\mathrm{p}<0.05)$ 。また， F1 区では 99\% と高率であった。精子の奇形率（Table 3）は, F1 (8.3\%) に比較して db/db (54.2\%), Adrex $(42.4 \%)$ および $\mathrm{db} /+(44.3 \%)$ は, 有意に高かった。し かし, 副腎摘出により $\mathrm{db} / \mathrm{db}$ の奇形率は有意に減少し た $(\mathrm{p}<0.01)$ 。授精後 120 時間までの培養成績を(Table 4）に示した。授精後 24 時間における 2 細胞期への発生 率は, $\mathrm{db} / \mathrm{db}$ 区の $67 \%$ を除き他の区では 90〜100\% と 高率であった。授精後48時間に 4 細胞期に発生した胚の 割合は, db/db 区で $31 \%$, Adnex 区で $43 \%$ と F1 区 (69\%) に比較して有意に低かった（p<0.05）。しかし， $\mathrm{db} /$ +区 $(54 \%)$ では，F1 区と比べ差がなかった（p> 0.05)。授精後72時間の桑実胚 および 授精後96時間の胚 盤胞への発生率については, db/db 区, Adrex 区および

Table 4. Preimplantation development of $\mathrm{C} 57 \mathrm{BL} / \mathrm{KsJ}-\mathrm{dbm}$ mouse embryos fertilized in vitro

\begin{tabular}{|c|c|c|c|c|c|c|}
\hline \multirow{3}{*}{$\begin{array}{l}\text { Genotype } \\
\text { of male }\end{array}$} & \multirow{3}{*}{$\begin{array}{l}\text { No. of } \\
\text { embryos } \\
\text { cultured }\end{array}$} & \multicolumn{4}{|c|}{ No. (\%) of embryos developed to: } & \\
\hline & & \multirow{2}{*}{$\frac{2-\text { cell }}{(24 \mathrm{hr})^{3)}}$} & \multirow{2}{*}{$\frac{4 \text {-cell }}{(48 \mathrm{hr})^{3)}}$} & \multirow{2}{*}{$\begin{array}{l}\text { Morula } \\
(72 \mathrm{hr})^{3)}\end{array}$} & \multicolumn{2}{|c|}{ Blastocyst } \\
\hline & & & & & $(96 \mathrm{hr})^{3)}$ & $120 \mathrm{hr})^{3)}$ \\
\hline $\mathrm{db} / \mathrm{db}$ & 61 & $41 \quad(67)^{a}$ & $19(31)^{a}$ & $11(18)^{a}$ & $10(16)^{a}$ & $17(28)^{\mathrm{a}}$ \\
\hline Adrex ${ }^{1)}$ & 74 & $74(100)^{\mathrm{b}}$ & $32(43)^{a, b}$ & $22(30)^{\mathrm{a}}$ & $17(23)^{\mathrm{a}}$ & $29(39)^{\mathrm{a}, \mathrm{b}}$ \\
\hline $\mathrm{db} /+$ & 28 & $28(100)^{b}$ & $15(54)^{\mathrm{b}, \mathrm{c}}$ & $4(14)^{a}$ & $8(29)^{\mathrm{a}}$ & $14(50)^{\mathrm{b}, \mathrm{c}}$ \\
\hline$F 1^{2)}$ & 77 & $69(90)^{\mathrm{b}}$ & $53(69)^{\mathrm{c}}$ & $36(47)^{b}$ & $40(52) \mathrm{b}$ & $47(61)^{\mathrm{c}}$ \\
\hline
\end{tabular}

1) Adrenalectomized $\mathrm{db} / \mathrm{db}$.

2) $\mathrm{C} 57 \mathrm{BL} / 6 \mathrm{~J} \times \mathrm{C} 3 \mathrm{H} / \mathrm{HeN}$.

3) Hours after insemination.

Values with different superscripts are significantiy different in the same column at $\mathbf{P}<0.05$.

Table 5. Offspring developed from C57BL/KsJ-dbm (db/db) mouse embryos fertilized in vitro and transferred to recipient mice

\begin{tabular}{|c|c|c|c|c|c|}
\hline \multirow{2}{*}{$\begin{array}{l}\text { No. of embryos } \\
\text { transferred }\end{array}$} & \multirow{2}{*}{$\begin{array}{l}\text { No. of pregnant/ } \\
\text { no. of recipient } \\
(\%)\end{array}$} & \multirow{2}{*}{$\begin{array}{c}\text { No. of } \\
\text { implantations } \\
(\%)\end{array}$} & \multicolumn{3}{|c|}{ Newborn } \\
\hline & & & No. $(\%)$ & $\mathbf{F}$ & $\mathbf{M}$ \\
\hline 77 & $8 / 12(67)$ & $26(34)$ & $11(14)$ & 3 & 8 \\
\hline
\end{tabular}

Two-cell stage embryos were transferred into the oviducts of MRL/MpJ females on day 0 of pseudopregnancy. 
$\mathrm{db} /+$ 区の 3 区間に差は認められなかったが，授精後 120 時間にお打る胚盤胞への発生率は，4 細胞期への発 生率と同様の傾向が認められた。

実験 III 合計77個の 2 細胞期胚を 12 例の受容雌に移 植した結果 (Table 5)，8 例が妊娠に至り，このうち7 例の受容雌から, 移植胚の $14 \%$ に相当する11例（䧳 : 雄=3:8）の生存産仔が得られた。なお, 分婏例 7 例の らち 4 例は，帝王切開によるものであった。

\section{考察}

$\mathrm{C} 57 \mathrm{BL} / \mathrm{Ks} \mathrm{J}-\mathrm{dbm}$ マウスの䧳雄ともに妊孕能を持 たないホモ個体同士の繁殖が，体外受精技術を用いるこ とにより可能となることが判明した。Johnson and Sidman (1979) は, db/db 雌マウスでは, GnRH の放出異 常が不妊の原因であり，卵巣は性腺刺激ホルモンに対す る感受性を有していると考察している。本実験にお梳る PMSG-hCG 法による排卵誘起処置の結果は, 彼らの主 張を裏付けるものであった（Table 1)。嶋川ら（1985） は，遺伝性の肥満動物である Zucker fatty ラットにつ いて, 雄ラットに副腎摘出を施すことにより生殖能力が 改善されることを報告した。さらに，副腎摘出は肥満マ ウスである ob/ob および $\mathrm{db} / \mathrm{db}$ にも適用し得ると推 察しているが，本実験における予備試験の結果では, $\mathrm{db} / \mathrm{db}$ マウスに対する副腎摘出は, 体重増加および尿糖 の出現を抑制することはできだものの, 妊孕能の回復 には至らなかった。しかし，体外受精成績においては (Table 2), 副腎摘出の顕著な改善効果が涩められ, db/ $\mathrm{db}$ 区の $24 \%$ に対し，Adrex 区では $41 \%$ と有意に高 まった $(\mathrm{p}<0.05)$ 。体外受精率におよぼす副腎摘出の効 果の要因については，本実験では明らかにされなかった が, 精子の奇形率の改善がその一因かも知れない(Table 3)。なおプレインキュベート後の精子の活力は，F1 精 子と比較すると劣るものの，いずれの遺伝子型に打い ても比較的良好であった。授精後 120 時間までの培養成 績（Table 4）では，F1 区と比較して $\mathrm{db} / \mathrm{db}$ 区および Adrex 区で， 4 細胞期以降の発生率が有意に低かった。 授精後 6 時間における観察において，第 2 極体放出途上 の卵子や第 2 極体は有してはいるが，雌雄の両前核が明 瞭でない卵子が認められたことから，着床前の発生率が 低いことは，精子の侵入時期の遅れに起因する発生の遅 れを示していると推察される。また，F1 区の比較的低 率な 4 細胞期以降の発生率は, 卵子側の要因はもとより, 過度の多精子受精によることも考えられ, 至適精子濃度 の検討が必要である。Adrex 区の 2 細胞期胚の移植に
よって生存産仔が得られたことにより（Table 5)，体外 受精技術の実験動物, 特に貴重な病態モデル動物の繁殖 維持への応用の可能性が示唆された。今後, 左右の卵管

（子宮）に遺伝的に異なる肧を移植し分けて，胎仔治療 あるいは薬効評価の検討を図るなど，体外受精一培養一胀 移植系を活用した新しい実験系の開発も期待される。特 に遺伝性疾患モデル動物において,明らかなホモ個体(発 症個体）作出が可能となると, 胎生期および新生仔期等 の発症前の動物による実験が計画できる。

\section{References}

Hoppe PC, Pitts S (1973) Fertilization in vitro and development of mouse ova. Biol Reprod 8: 420426.

Hoshi M, Toyoda Y (1985) Effect of EDTA on the preimplantation development of mouse embryos fertilized in vitro. Jpn J Zootech Sci 56: 931-937 (in Japanese).

Johnson LM, Sidman RL (1979) A reproductive endocrine profile in the diabetes (db) mutant mouse. Biol Reprod 20: 552-559.

Kasai K, Minato Y, Toyoda Y (1978) Fertilization and development in vitro of mouse eggs from inbred strains and F1 hybrids. Jpn J Anim Reprod 24: 19-22.

Kasai K, Sugimoto M, Toyoda Y (1979) Normal progeny produced by the parent derived from mouse eggs fertilized in vitro. Jpn J Zootech Sci 50: $885-890$.

Massip A, Van der Zwalmen P, Puissant F, Camus M, Leroy $F$ (1984) Effects of in-vitro fertilization, culture, freezing and transfer on the ability of mouse embryos to implant and survive. J Reprod Fert 71: 199-204.

Mukherjee AB (1972) Normal progeny from fertilization in vitro of mouse oocytes matured in culture and spermatozoa capacitated in vitro. Nature 237: 397-398.

Mukherjee AB, Cohen MM (1970) Development of normal mice by in vitro fertilization. Nature 228 : 472-473.

Shimakawa Y, Oomari Y, Masaki T, Odaka Y, Sano $\mathrm{Y}$, Matsuo $\mathrm{T}$ (1985) unpublished.

Suzuki H, Toyoda Y (1986) Normal young from in vitro fertilized mouse embryos developed in a medium supplemented with EDTA and transferred to pseudopregnant recipients. J Mamm Ova Res 3: 78-85.

Toyoda Y, Yokoyama M, Hosi T (1971a) Studies on the fertilization of mouse eggs in vitro. I. In vitro fertilization of eggs by fresh epididymal sperm. Jpn J Anim Reprod 16: 147-151 (In Japanese). 
Toyoda Y, Yokoyama M, Hosi T (1971b) Studies on the fertilization of mouse eggs in vitro. II. Effects of in vitro pre-incubation of spermatozoa on time of sperm penetration of mouse eggs in vitro. Jpn J Anim Reprod 16: 152-157 (In Japanese).

Whitten WK (1971) Nutrient requirements for the culture of preimplantation embryos in vitro. Advan Biosci 6: 129-141.

Whittingham DG (1968) Fertilization of mouse eggs in vitro. Nature 220: 592-593.

Yokoyama M, Kojima H (1985) unpublished.

\section{要}

約

遺伝性の肥満性糖尿病を呈する C57BL/Ks J-dbm マウスを用い, 雌雄共に妊孕能のない発症個体 $(\mathrm{db} / \mathrm{db})$ 間の体外受精・培養および産仔への発生能について検討した。 $\mathrm{db} / \mathrm{db}$ に PMSG-hCG 法 により排卵誘起を施し, $\mathrm{db} / \mathrm{db}$, 副腎摘出 $\mathrm{db} / \mathrm{db}$ (Adrex), $\mathrm{db} /+$ および (C57BL/6J $\times \mathrm{C} 3 \mathrm{HeN}) \mathrm{F} 1$ の精栄上体精子を用いて体外受精を行った。F1 区の受精率に比べ，Adrex 区 $\mathrm{db} / \mathrm{db}$ 区および $\mathrm{db} /+$ 区では低率であったが，体外受精率に及ぼす副腎摘出の有意な効果が認められた。また，Adrex 区 の 2 細胞期胚の移植により，移植胚の $14 \%$ に相当する11例の産仔が得られた。 